\title{
WOMEN IN ENGLISH PHILANTHROPY
}

\author{
I790-1830*
}

Students of institutional charity must sometimes share Walter Bagehot's melancholy doubt "whether the benevolence of mankind does most harm or good"; 1 but they do not dispute that philanthropists were ubiquitous in England by the middle decades of the nineteenth century. Sir James Stephen called the period the age of charitable societies. "For the cure of every sorrow [...] there are patrons, vicepresidents, and secretaries. For the diffusion of every blessing [..] there is a committee."2 Many issues raised by the expansion of philanthropy have been treated with considerable insight. But at least one question has largely escaped the historian: the role of charitable women among the "Fathers of the Victorians".

Generations of scholars have accepted women as charitable in their habits, and now and then they have raised the exceptional female philanthropist to the level of biography. But they have not been much interested in the origins or scope of women's participation in organized charity, and they have little idea of the impact of social forces upon female generosity. ${ }^{3}$ This study tackles the problem on a numerical basis, and is confined to the years $1790-1830$, decades in which a significant amount of published data is available from charitable societies. After establishing the proportion of women involved in these societies and in what way their numbers altered, we may look to the literary evidence for explanations. Were women an important force in the philanthropy of the period, and if so, what were their motives and what was the nature of their impact?

In his researches, Ford K. Brown discovered approximately 160

* I would like to thank my friends Robert and Susan Youngs for their generous help.

1 Walter Bagehot, Physics and Politics (London, 1872), pp. 188-89.

2 Sir James Stephen, Essays in Ecclesiastical Biography (2 vols; London, 1849), I, p. 382 .

${ }^{3}$ Working primarily from wills, W. K. Jordan has put together some very interesting statistical material on the role of women in philanthropy in the years 1480-1660. See Philanthropy in England, 1480-1660 (London, 1959). 
religious, moral, educational, and philanthropic organizations founded in England between 1700 and 1830.1 (This figure does not include auxiliaries, alms-houses, friendly societies, hospitals, infirmaries, or dispensaries.) About 130 of these were established in the years 17901830 , a convincing proof of the advance in institutional philanthropy during that period. Roughly 125 societies were active for a decade or more during the years 1790-1830; and in the vast majority of these all the elected and appointed officers were men. (I have found 11 charities governed by women which were active for ten years during the period.) Of these 125 societies I have uncovered 45 that published at least one subscription list, and 20 that published lists for two or more separate years. These 20 , all of them managed by men, permit an analysis of numerical growth or decline for the years 1790-1830. A study of their subscription lists should enable us to make a fair assessment of the pattern of female contributions to male dominated charity. In size and wealth these better documented societies have a greater significance than their numbers suggest, for they include many of the larger charities, amongst them the Church Missionary Society, the British and Foreign Bible Society, the Mendicity Society, the Society for Bettering the Condition of the Poor, the Religious Tract Society, the Society for the Promotion of Christianity amongst the Jews, and the Society for Promoting Christian Knowledge.

Subscription lists, though normally limited to name, date, sex, and the amount of each individual's contribution, are reasonably reliable. Dependent on public support, charities were very conscious of the need to keep financial and personal details in good order. Secretaries and professional accountants made every effort to provide accurate information, and in their accounts they often included addenda and asked readers to correct mistakes and mention omissions. My principal difficulty was that I frequently encountered lists with anonymous donors, simply initials, or collections from churches or other societies. Except in the case of donations from ladies' societies, which I counted as female subscriptions, and long lists of church collections, which I omitted, I consistently counted these anonymous contributions as male. Thus my percentages of women in the various charities err on the low side. But as the anonymous subscribers rarely make up a significant percentage of the overall list, my figures should not be much affected, perhaps by three percent at most. ${ }^{2}$ Another problem

1 Ford K. Brown, Fathers of the Victorians (Cambridge, 1961), pp. 333-40. The figure is not exact because several societies cannot be dated and others may be repeated in Brown's list under different names. I have found some that do not appear in his list.

2 The percentage of women subscribers would probably increase considerably if 
raised by the lists is that they are often restricted to London. This is to be expected, however, since London was the nation's wealthiest city and the headquarters for so many of the charities. From the provincial lists that I have seen, there is no evidence to suggest that women were less active outside London. If anything, they were more so, for by 1830 there were thousands of provincial ladies' auxiliaries, ranging in the size of their membership from a handful to hundreds.

Virtually all of the 20 societies with two subscription lists that I have examined were growing rapidly at some time during the period 1790-1830. The most remarkable feature was the dramatic rise in the percentage of women contributors within these expanding charities (see Appendix I). In 17 out of 20 cases their numbers increased quite considerably, and this was particularly true of the larger charities. In the Church Missionary Society accounts of 1801, for example, only $12 \%$ of the London subscribers were female and no auxiliaries were listed. By 1823, the figure was $29 \%$, and in the provinces scores of ladies' auxiliaries were active. In $1802,14 \%$ of the total number of subscribers to the Benevolent, or Strangers' Friend Society were women. In 1826 , women made up $32 \%$ of the total. In the four years between 1809 and 1813, the proportion of women rose from 12 to $27 \%$ in the Society for the Promotion of Christianity amongst the Jews. (In the provincial auxiliaries their contribution was even greater by 1813.) In the major tract societies, the Society for Promoting Christian Knowledge, the British and Foreign Bible Society, the Religious Tract Society, and the Prayer-Book and Homily Society, the percentages rose from 10 to $20 \%$ (1790-1817), 12 to $23 \%$ (1805-1817), 11 to $24 \%(1801-1829)$, and 10 to $20 \%(1814-1830)$ respectively. In Sir Thomas Bernard's distinguished Society for Bettering the Condition of the Poor, the proportion jumped from 13 to $31 \%$ in only seven years (1798-1805). In the three charities where the percentage of women subscribers did not rise, it remained almost constant. But it should be added that the level of female participation in these societies, the Lying-in Charity, the Guardian Society, and the Philanthropic Society, was relatively high in the earlier lists, $30 \%, 27 \%$ and $22 \%$ respectively.

In those 25 charities for which I found only one subscription list, it is impossible to establish any trend in the contribution of women (see Appendix II). These lists, however, do give an impression of the kind of benevolence that interested them. Here, as in the aforementioned societies, their role was conditioned by the nature of the

we knew the number of joint donations, suggested by wives but usually put in the husband's name. 
charity and the management's connections. And, as might be expected, the percentage of women varied considerably. In the minuscule Institution for Rendering Assistance to Shipwrecked Mariners, the sole female subscriber in 1809 was its patroness, the Princess of Wales. But in the Loan Society, founded to aid impoverished gentlefolk, nearly two out of three subscribers were women by 1817. Perhaps because of the indelicate nature of the charity, the City of London Truss Society for the Ruptured Poor listed only 55 women among its 1,203 subscribers in 1821.' William Wilberforce's Society for the Suppression of Vice, on the other hand, contained a great many ladies, $31 \%$ of the subscribers after only one year of operation. Unfortunately, the figures for the anti-slavery societies are incomplete for the years 1790-1830. Subscription lists for Granville Sharp's Society for the Abolition of Slavery, established in 1787, are unavailable after 1788 . At that early date $11 \%$ of the contributors were female. ${ }^{2}$ In the Anti-Slavery Society formed under the leadership of Zachary Macaulay in 1823, the lists are so heavily weighted with donations from auxiliaries that it is impossible to set an accurate percentage of women. But the number of ladies' anti-slavery auxiliaries or associations is revealing in itself; by 1830 there were scores of them. ${ }^{3}$

The contribution of women to charitable institutions in purely financial terms is difficult to assess. Many societies did not include the amount of contribution in their subscription lists; in others the sheer bulk of information makes the task of isolating the figures for women a formidable one. Be that as it may, a sample from several societies in which the evidence is relatively easy to manage may be useful. In the accounts for 1809 of the Society for the Promotion of Christianity amongst the Jews, women made up $12 \%$ of the donaters and subscribers and contributed $11 \%$ of the funds, $£ 37$ out of $£ 342 .{ }^{4}$ Women made up $8 \%$ of the subscribers and provided $7 \%$ of the funds in the Society for the Diffusion of Knowledge upon the Punishment of Death in the years 1810 and $1811, £ 33$ out of $£ 493$. In the Church Missionary

\footnotetext{
1 The object of this society was to provide trusses and bandages, perform operations, and supply medicines to the vast number of persons with bernias, estimated at one in eight of the population. City of London Truss Society, for the Relief of the Ruptured Poor (London, 1818), p. 3.

2 List of the Society Instituted in 1787, for the Purpose of Effecting the Abolition of the Slave Trade (London, 1788). There were 860 subscribers in this year, 94 women.

${ }^{3}$ See An Account of the Receipts and Disbursements of the Anti-Slavery Society, for the Years 1829 and 1830 (London, 1830).

4 The financial figures in this paragraph are to the nearest pound. The sources of the information can be found in the appropriate account listed under "Sources" in the appendices.
} 
Society records for 1801 , women gave $£ 15$ out of a total of $£ 178$ from subscriptions, $8 \%$, while making up $12 \%$ of the subscribers. In other charities women paid their full share and more. In the Philanthropic Society's list for 1816 , women made up $22 \%$ of the subscribers and contributed $22 \%$ of the money, $£ 402$ out of $£ 1,854$. In the PrayerBook and Homily Society's accounts for $1814,12 \%$ of the donations and subscriptions, $£ 77$ out of $£ 670$, came from women, but only $10 \%$ of the subscribers were female. And in the Royal Jennerian Society, where there was a high percentage of aristocratic patronage, the women subscribers, $7 \%$, donated $9 \%$ of the funds in $1803, £ 258$ out of $£ 2,748$. These six examples are far from a conclusive sample, but they do give reason to believe that the financial contribution of women to institutional charity was very nearly in proportion to their member numbers.

The growing interest of women in charities managed by men was paralleled by what can only be described as an explosion of female societies, i.e. those (not auxiliaries) in which ladies' committees made policy. Until the opening of the Charity for Female Emigrants in 1795, the only female charity of which I have found any record in the eighteenth century was the Ladies' School of St Sepulchre, founded in 1702.1 By contrast, the period 1795-1830 saw the emergence of no fewer than 17 ladies' societies, several of them with numerous provincial auxiliaries. Fortunately, some of the parent societies have left accounts. In its report of 1803, for example, the Friendly Female Society, for the Relief of Poor, Infirm, Aged Widows, and Single Women (founded 1802) listed 442 women out of the 500 subscribers $(88 \%) .^{2}$ The Ladies' Charity School of St Sepulchre, still active in the nineteenth century, reported a total of 325 subscribers in 1805, 270 of them women $(83 \%) \cdot{ }^{3}$ The Ladies' Royal Benevolent Society (founded 1812) boasted 980 donors in 1817,805 of them women $(82 \%){ }^{4}$ And in 1828 the British and Irish Ladies' Society (founded 1822) numbered 303 women among its 324 subscribers $(94 \%) .5$ These charities com-

\footnotetext{
1 There were, of course, many examples of Female Benefit Societies or Friendly Societies established by women in the eighteenth century. See Catharine Cappe, Observations on Charity Schools, Female Friendly Societies, and Other Subjects Connected with the Views of the Ladies' Committee (York, 1805).

2 The Friendly Female Society, for the Relief of Poor, Infirm, Aged Widows, and Single Women (London, 1803).

3 Plan of the Ladies' Charity School of St. Sepulchre (London, 1805).

4 The Ladies' Royal Benevolent Society (London, 1818).

${ }^{5}$ Fifth Report of the British and Irish Ladies' Society (London, 1828). The other ladies' societies founded between 1795 and 1830 were: the Charity for the Relief of Female Emigrants (1795), the Ladies' Society for the Education and Employment of the Female Poor (1804), the Female Friendly Union Society (1806), the
} 
pared in size with the medium scale men's institutions; the percentage of men in them, it should be noted, was low. It can be assumed that the emergence of the ladies' societies had the effect of draining off some of the support that women might have been expected to give to the men's charities. This makes the increased contributions of women to the societies run by men all the more impressive. All in all, whether adding their wealth and talent to men's institutions, or enlisting in the burgeoning ladies' societies, women were being attracted to philanthropy in unprecedented numbers. They were an extremely important force behind the rapid expansion of charity in the years 1790-1830.

Many of the women represented in the subscription lists, whether patronesses, committee members, or simply contributors, were nonparticipants. They salved their consciences by lending their names or by annual donations to charity. Yet there is no reason to suppose that women were more often inactive than their male counterparts. Indeed, having more leisure they were more involved. Leisured women were the backbone of the rapidly expanding system of district visiting, and it might be argued that the system would have been unworkable on a large scale without them. By 1830 women carried out hundreds of thousands of visits annuaily. ${ }^{1}$ But it was not only in the homes of the poor, "by the beds of misery and want" that "she pour'd instruction and gave relief". ${ }^{2}$ In the early decades of the nineteenth century women worked all over England in lying-in charities, asylums for the deaf, blind, destitute and insane, ${ }^{3}$ soup kitchens, village shops, libraries, chapels, schools, and hospitals. They deemed such duties their particular calling. Compassion and tenderness were, after all, considered to be peculiarly feminine virtues. They were also virtues which the exercise of charity would not coarsen. When writing about

London Society for the Encouragement of Faithful Female Servants (1812), the Society of Young Ladies to Sell Clothes at Reduced Prices (1812), the Dorcas Society (1813), the Ladies' Benevolent Society for the Relief of poor married Lying-in Women (1813), the Southwark Female Society (1813), the British Society of Ladies for Promoting the Reformation of Female Prisoners (1821), the Royal Female Philanthropic Society (1822), the Ladies' Hibernian Female School Society (1823), the Invalid Asylum for Respectable Females (1825), the Ladies' Society for Promoting education in the West Indies (1825), and the Philo-Judaean Ladies' Association (1826).

1 Brown, Fathers of the Victorians, p. 240.

${ }^{2}$ Mrs. Maddocks, The Female Missionary Advocate (London, 1827), p. 10.

3 The campaign to open lunatic asylums to women visitors, initiated in the early nineteenth century, is discussed in Catharine Cappe, Thoughts on the Desirableness and Utility of Ladies Visiting the Female Wards of Hospitals and Lunatic Asylums (London, 1816). 
their labours among the poor, women often spoke of their special relationship with other women. "A person of modest mind will open her situation to one of her own sex", remarked one editor. ${ }^{1}$ Men agreed, and when women sought to organize their own societies for the benefit of their sex they gave encouragement. "You have wisely taken the management of this great concern into your own hands", said the Rev. Dr Hunter in his address to the founders of the Friendly Female Society in 1802. And he added the telling comment: "You stand in no need of male assistance. It is one of those domestic businesses in which it were indecent for men to interfere."2

It is fair to say that in the majority of charities men made policy and women did much of the routine and thankless labour. In a few of the societies governed by men, women did act in positions of some importance. In the Loan Society, for instance, they advised on financial matters ; ${ }^{3}$ in the Forlorn Female Institution (Fund of Mercy) they interviewed prostitutes $;{ }^{4}$ and in the Society for Bettering the Condition of the Poor they contributed articles to annual reports on topics ranging from banking to midwifery. ${ }^{5}$ But such activities were about as close as they came to policy-making. In the emerging female charities, however, they had a more direct responsibility. Here they not only came into daily contact with the objects of their generosity, but they drew up regulations, elected officers, took minutes, oversaw accounts and publications and, very importantly, solicited subscriptions and corresponded with other ladies' societies. Women were severely restricted in their opportunities for formal education, but through institutional charity they were slowly learning administrative skills. As John Stuart Mill wrote in 1861, "there are few of the administrative functions of government for which a person would not be fit, who is fit to bestow charity usefully". ${ }^{6}$ This comment was particularly apt when the women's suffrage movement in England got under way a few years after he wrote.

In the years $1790-1830$, the majority of women who were picking up the skills associated with institutional charity were middle class.

1 The Friendly Female Society, for the Relief of Poor, Infirm, Aged Widows, and Single Women, p. 4.

2 Ibid., p. 14.

3 The Second Annual Report of the Loan Society (London, 1817), p. 3.

4 Fund of Mercy; or an Institution for the Relief and Employment of Destitute and Forlorn Females (London, 1813), p. 6.

${ }^{5}$ Women also wrote on schools, soup kitchens, recipes, libraries, contagious fever, and regulations governing their own auxiliaries for the Society for Bettering the Condition of the Poor.

- The Rights of Woman by Mary Wollstonecraft and the Subjection of Women by John Stuart Mill (London, 1929), p. 315. 
Titled ladies also participated in considerable numbers and were especially prominent, in both men's and ladies' societies, as patronesses. From the evidence of subscription lists there is no reason to suggest that middle-class women were increasing their influence at the expense of the titled before 1830. In the early nineteenth century, the number of titled women varied from society to society, depending on their affiliations. In the Religious Tract Society, nonconformist in origin, no titled female subscribers were listed in the report of $1801 .{ }^{1}$ In other institutions, particularly those with royal patronage, roughly 5 to $25 \%$ of the women subscribers were titled, a figure that remained more or less constant during the period. ${ }^{2}$ The precise number of married or widowed women is difficult to determine and easy to overstate, because of the custom common among spinsters of using Mrs in later life. There is ample evidence that a considerable number of single women subscribed to the societies and that they saw their philanthropic activities as a means of offsetting the prejudice against their marital status. ${ }^{3}$ Given the present state of research it is hazardous to make a connection between late marriage, which demographers tell us was a major feature of English family life, and women's charitable work. ${ }^{4}$

Single or married, the great majority of the female subscribers to the various charities were leisured. Yet, at the other end of the social scale, domestic servants made occasional donations, most notably to the highly popular Society for Promoting Christianity amongst the Jews. Whether these labouring women gave spontaneously or were invited to give by their superiors is open to question. At any rate, their numbers and contributions were such as to make their impact negligible.

Subscribing servants may have been among those rehabilitated by the privileged classes. Almost every generation of leisured women in England thought itself badly served by domestics; and this was particularly true at the beginning of the nineteenth century. ${ }^{5}$ The

1 See The Second Annual Report of the Religious Tract Society (London, 1801).

2 The highest proportion of titled ladies that I found was in the Royal Jennerian Society, where 19 out of the 29 female subscribers were titled, 66 per cent. See Address of the Royal Jennerian Society for the Extermination of Small-Pox (London, 1803).

${ }^{3}$ See, for example, Cappe, Observations on Charity Schools, p. x.

4 Lawrence Stone suggests that there was a connection between late marriage and women in school teaching. But I would hesitate to argue that philanthropy was also taken up because of late marriage. It was, after all, unpaid work. Lawrence Stone, "Literacy and Education in England 1640-1900", in: Past and Present, No 42 (1969), p. 95.

5 For a discussion of domestic servants see Dorothy Marshall, "The English 
moral climate and the relative refinement of the age combined to make increasing demands on servants. Furthermore, privileged ladies, anxious to divert themselves outside the home, had to depend more and more on the honesty and industry of domestic help. To their dismay, they found their servants very often untrained and unreliable. The "degeneracy" of domestic servants in the last thirty years, wrote one lady in 1830, "is universally felt, admitted, and lamented". ${ }^{1}$ Another blamed the chronic shortage of adequate staff on the faulty training that servants received from their betters. ${ }^{2}$ To such women the way to an orderly household was to be found in Christian principle and early education. Aware that their own emancipation depended on the growing servant class, they set themselves to work.

The Ladies' School of St Sepulchre became little more than a preparatory school for domestics. ${ }^{3}$ The Ladies' Society for Educating and Employing the Female Poor put the training of servants and governesses near the top of its list of priorities. ${ }^{4}$ In 1792 the British Society for the Encouragement of Servants was founded, and twenty years later the London Society for the Encouragement of Faithful Female Servants. Around the country industrial schools opened to teach working-class girls domestic skills and the habits of honest industry. The charitable ladies also tried to look after their charges in sickness and old age. The Fund of Mercy was founded in 1812 to relieve forlorn and virtuous servants; and in 1825 the Invalid Asylum for Respectable Females gave a home to sick women formerly employed by the rich. ${ }^{5}$ Yet the suffering was too immense for the limited remedies of private philanthropy. The rising interest of charitable women in the plight of servants could not even keep pace with the problem.

The most obvious reason for the rising number of women in philanthropy was the change brought about in English life by industrialization. ${ }^{6}$

Domestic Servant in History", for the Historical Association (London, 1949). See also J. Jean Hecht, The Domestic Servant Class in Eighteenth-Century England (London, 1956).

1 A Country Lady, Females of the Present Day, considered as to their influence on Society (London, 1831), p. 78.

2 Sarah Trimmer, The Oeconomy of Charity (2 vols; London, 1801), II, pp. 3-4.

3 Plan of the Ladies' Charity School of St. Sepulchre, pp. 5-8.

'Extract from an Account of the Ladies' Society, for the Education and Employment of the Female Poor (London, 1804), p. 2.

5 The female benefit societies also worked to relieve retired domestic servants. See Cappe, Observations on Charity Schools, pp. 145-46.

6 According to B. R. Mitchell, Abstract of British Historical Statistics (Cambridge, 1962) the proportion of females in the population of England and Wales fell during the period. Thus increasing female activity in charity cannot be explained by any rise in their numbers relative to the number of men. (Mitchell 
For the poor it brought massive social dislocation which, in an age of little government intervention, made increasing demands on private charity. For many middle-class women, on the other hand, industriali-, zation brought increased wealth, greater reliance on servants, and fewer occupations. It helped to free them from their domestic duties but offered them little escape from lives of refined idleness. Women had traditionally played an important part in certain trades and professions, but denied advanced training in an age that increasingly demanded specialized knowledge, they were being replaced by better qualified men. ${ }^{1}$ At the same time, added income made more and more women, the wives of tradesmen for example, aspire to a life of less responsibility and more freedom; little did they realize that what they would gain in independence they would lose in opportunity. By the middle decades of the nineteenth century there was not much employment suited to middle-class women outside writing, dressmaking, millinery work, and governessing; and it could be said that "a lady, to be such, must be a mere lady, and nothing else. She must not work for profit, or engage in any occupation that money can command, lest she invade the rights of the working classes". ${ }^{2} \mathrm{Her}$ frequent complaint was of having nothing to do. Others complained that she gave in too easily to dissipation and the fine arts. And some, very sensibly, offered her new possibilities. Hannah More (a pioneer of the charity school movement) believed that "the time and money [...] snatched from vain and frivolous purposes, are more wisely directed together into the same right channel of Christian Benevolence". ${ }^{3}$ Benevolence, wrote the learned Catherine Macaulay, was one of the most "animating of the moral principles", and if genuinely practised by the fashionable it would "entirely subdue the daemon Ennui".4 Ladies took the advice to heart, but in doing so they made charity a branch of fashion, a sign of status, and a justification of wealth.

Ironically, the people who sought to engage privileged women in charity were often those who railed against benevolence becoming fashionable. Hannah More came to decry the worldliness of many

estimates that there were 1,057 females for every 1,000 males in 1801 , and 1,040 per 1,000 in 1831 , p. 6 .)

1 I am much indebted in this section to the pioneering work of Ivy Pinchbeck, Women Workers and the Industrial Revolution, 1750-1850 (London, 1930).

2 From Margaretta Greg's Diary, quoted in Pinchbeck, Women Workers and the Industrial Revolution, 1750-1850, p. 315. In a letter to the Times, December 26, 1801, "The Females' Friend" asked for a charity to be instituted for the impoverished middle-class woman, for "she cannot work - she cannot beg".

${ }^{3}$ Hannah More, Moral Sketches of Prevailing Opinions and Manners (London, 1819), p. 214.

- Catherine Macaulay Graham, Letters on Education (London, 1790), p. 290. 
philanthropists of her sex. Another writer, a "Country Lady", argued that charitable women were far too often "tea and Bible" friends, who degraded religion and neglected their domestic duties. She went on to call for a less artificial benevolence, but she hailed that salutary maxim, "charity begins at home". ${ }^{1}$ Mrs Macaulay's fear that the gay and rich would raise "insurmountable obstacles" to genuine philanthropy was justified. ${ }^{2}$ But it is difficult to imagine how it could have been otherwise. Enlightened men like Sir Thomas Bernard of the Society for Bettering the Condition of the Poor, or Sir James Mackintosh in his activities for the West London Lancastrian Association spent much of their time in drawing rooms persuading rich ladies to contribute to causes which they did not understand. ${ }^{3}$ In order to open purses, they often had to make charity sound like an amusement, "the gaming Table without its Horrors" to use Bernard's phrase. ${ }^{4}$ A man who could attract the ladies and tap their considerable wealth was a valuable asset to any philanthropic society.

Pressure to contribute also came from the family magazines, which were coming into vogue at the end of the eighteenth century through the efforts of Sarah Trimmer and other didactic women. ${ }^{5}$ In such periodicals as the Family Magazine (1788), the Female Preceptor (1813-15), and the Female Instructor (1811-30) snobbery combined with the most pious sentiment to make a plea for charity. It was rather out of place in the context. One minute the editors encouraged women to renounce the world and aid the poor; the next they laid down rules on how to capture a husband and enjoy the spoils. Insensitive and hypocritical, they made social pity into an ideal, while at the same time pandering to the weaknesses of their readers. The Female Instructor for 1830 included the following lines:

"Whilst the poor man groaneth on the bed of sickness, whilst the unfortunate languish in the horrors of a dungeon, or the hoary head of age lifts up a feeble eye to thee for pity; $O$ how canst thou riot in superfluous enjoyments regardless of their wants, unfeeling of their woes."'6

1 A Country Lady, Females of the Present Day, pp. 135-48; Hannah More, Strictures on the Modern System of Female Education (2 vols; London, 1799), I, passim.

2 Macaulay Graham, Letters on Education, p. 290.

3 Thos. Frognall Dibdin, Reminiscences of a Literary Life (2 parts; London, 1836), I, p. 231 ; Edward Wakefield to Francis Place, December 1, 1813, British Museum, Add. Mss 35752, ff. 10-11.

4 Pleasure and Pain, 1780-1818, ed. by J. Bernard Baker (London, 1930), p. 55.

5 For a discussion of women's magazines see Alison Adburgham, Women in Print (London, 1972).

- The Female Instructor; or Young Woman's friend and Companion (London, 1830), p. 165. 
Turn the page and there is an article on ladies' dress; on the previous page the story of "Theodora, a Christian virgin, condemned to the stews, where her chastity was to be a prey to all comers". 1

Appeals from family magazines, the pulpit and the platform, women writers, and fashionable gentlemen played an essential part in publicizing the cause. Never before had charity been solicited on such a scale. For many women the campaign simply turned privilege into virtue and made the subscription resemble an indulgence. But it would be unfair to malign the many others, some privileged, others not, who committed themselves from more noble motives. These were the women who, according to the impoverished poetess Mrs Maddocks, found their chief delight in "blessing others". ${ }^{2}$ They were also the ones who did so much of the humdrum work of the charitable societies. If for many women philanthropy was little more than a celebration of property, for these others it was a heartfelt duty, a duty expressed in

"Those thousand decencies which daily flow,

From all her words and actions."3

Many of those "thousand decencies" bore an Evangelical stamp. But was the Evangelical movement, so important in the expansion of charity by the early nineteenth century, particularly attractive to women? Certainly many important ladies with wide ranging social connections were zealous advocates of Evangelical benevolence. ${ }^{4}$ In those religious societies that can justly be labelled Evangelical, the British and Foreign Bible Society and the Church Missionary Society for example, the increase in the percentage of female subscribers was considerable. In most charities, however, including those decidedly Evangelical, Evangelical women were joined by high-church women, quakers, and other nonconformists in the common cause. Thus it would be a very difficult task to measure precisely the number of Evangelical women within them. We know quite a bit about the religious affiliations of the leading charitable ladies but unfortunately very little about the religious views of the majority of female subscribers. Nevertheless it is true that the Evangelicals expanded their influence on almost every charitable front in the early nineteenth century, and women were doing the same; hence it may be safe to infer that there was a connection. If so, it was probably forged by the

1 Ibid., p. 164.

2 Mrs. Maddocks, The Female Missionary Advocate, p. 11.

3 The lines are Milton's, quoted in Hannah More, Strictures on the Modern System of Female Education, I, p. 7.

4 For a list of the leading Evangelical ladies see Brown, Fathers of the Victorians, p. 358 . 
nature of the Evangelical revival, which placed morality and the affections above intellect and which opened its doors socially to women. Religious sensibility and social pity stood much higher in the minds of women like Hannah More than abstract, frequently arid, theology. And if right conduct and moral fervour were thought to be the preserve of women, it would only be natural for Evangelicalism, which put such a premium on manners and morals, to find a refuge in the female breast.

There is no doubt a grain of truth in the old cliche that the English became pious when the French became republican. Social historians tell us that a frightened English establishment became philanthropic to prevent the spread of democratic ideals and social unrest. But they have not asked themselves what effect, if any, French affairs had on the benevolence of women. Was "useful" charity the English woman's response to the conditions created by the crisis on the continent? There is evidence to suggest that this was so. In at least two of the ten ladies' societies established between 1795 and 1815 that I have discovered the motive was explicit. The Charity to Relieve Female Emigrants was set up in 1795 to aid French women and children in flight from the revolution. By 1797 its ladies' committee, headed by the Duchess of York, had expended over $£ 600$ on clothing, linen, sick care, and schooling. The number of beneficiaries was in the hundreds. ${ }^{1}$

Nor is there any doubt about the sentiments of the Ladies' Society for the Education and Employment of the Female Poor. In their preliminary report of July 1803, two months after the renewal of hostilities with France, the editors declared:

"At the present crisis, and probably for some years to come, the strength of every male arm will be wanted, for the defence and protection of our beloved and envied country. To women there can be opened, at best, but a limited scope of action; and it is for the benefit of all, looking to the increase of the general fund, that they should not be precluded, from contributing their portion of productive industry."

The "pestilential disease" that had corrupted the sanity of Europe must be fought on every front. To the women of the English establishment this meant fighting it in hospitals, soup kitchens, schools, chapels, the homes of the poor, and, if need be, in their own "dressing

\footnotetext{
1 A Short Account of the Charity Established for the Relief of Female Emigrants (London, 1797), p. 5.

2 The Reports of the Society for Bettering the Condition and Increasing the Comforts of the Poor, 5th ed. (6 vols; London, 1815), IV, p. 139.
} 
rooms". ${ }^{1}$ Distressed by the foreign element in their midst, many ladies were anxious to replace French and Italian servants with British ones. Coupled with the reduced mobility of servants during the Napoleonic wars, this campaign helps to account for the higher precentage of Britons in the nineteenth-century servant class.

As might be expected, English middle- and upper-class women were as apprehensive as men after 1793; and their charity betrayed the same concern as did the men's for social cohesion and the inculcation of approved social attitudes. The "revolution harpies of France, sprung from night and hell"'2 were never far from the female imagination; the church, the press, the family magazines, and the women writers made certain of that. Hannah More was in deadly earnest when she pleaded with women "to come forward and contribute their full and fair proportion towards the saving of their country". ${ }^{3}$ The same thought was passing through Sarah Trimmer's mind when she re-wrote her influential Oeconomy of Charity in 1800. "There is, at the present time, an imperious call for the exertions of every member of the community of the higher ranks to pay attention to the condition of the common people." 4 She spoke with particular pride of the "Ladies of Britain", who provided warm clothing for their "brave soldiers" suffering from cold on the continent. But in a time "when attempts are made to corrupt the minds of the common people in every possible way", charity schools, with lessons taught "systematically", were her principal concern. ${ }^{5}$ Nothing pleased her more than occasions like the anniversary celebration of London Charity Schools in St Paul's, when 7,000 poor children could be heard shouting in unison "long live the King". Working-class crowds in the streets, on the other hand, "each demanding, or at least expecting as their right a loaf of bread, or a bushel of coal", reminded her of nothing so much as a "seditious meeting". 6 To avoid such potentially dangerous scenes, she advised women to visit the poor in their cottages, which they were doing, in vastly increasing numbers.

Political and social unrest have often enhanced the status of women and stimulated their interest in good works. The English civil war had

1 Ibid., pp. 140-41. The Ladies' Society for the Education and Employment of the Female Poor would even have the "infected" French language banned but for its being so much in use in the schools.

2 Edmund Burke, A Letter from the Right Honourable Edmund Burke to a Noble Lord (London, 1796), p. 21.

3 More, Strictures on the Modern System of Female Education, I, p. 4.

- Trimmer, The Oeconomy of Charity, I, pp. xii-xiii.

Ibid., I, p. 156; II, p. 120.

- Ibid., I, p. 84; II, pp. 57-8. 
this effect; ${ }^{1}$ and, undoubtedly, this was part of the impact of the French revolution and the Napoleonic wars on English life. Of the 17 charities that showed a rise in the number of women subscribers, most showed a rise at some time during the years 1793-1815. But it would be rash to overstate the connection; for during these years there were other more profound forces at work, which pushed women in the direction of institutional charity. Continental affairs may best be viewed as an immediate, though recurring, cause of the increased participation of women. They worked to release reserves of the English woman's wealth, and significantly, they enhanced the conservative colour of her philanthropy.

The conservative nature of much late eighteenth- and early nineteenth-century charity is indisputable. One writer has gone so far (probably too far) as to say that in the counter-revolutionary decades the "humanitarian tradition became warped beyond recognition". ${ }^{2}$ At the heart of the matter was a potential conflict. The immediate effect of benevolence was to assist the necessitous; but could it be done without diminishing the general good? Philanthropists may be accused of feeding the poor and sapping their strength. Paternalistic, they too often rewarded the "deserving" and servile and discouraged the obstinate and self-respecting. The role of women in this may be explained by the nature of their disadvantages. As their own blessings were dependent upon the arbitrary benevolence of men, they tended to lapse into the most arbitrary benevolence themselves. And not being free themselves, working-class independence meant little, if anything, to them. "The education of women", wrote John Stuart Mill,

"- an education of the sentiments rather than of the understanding - and the habit inculcated by their whole life, of looking to immediate effects on persons, and not to remote effects on classes of persons - make them both unable to see, and unwilling to admit, the ultimate evil tendency of any form of charity or philanthropy which commends itself to their sympathetic feelings."3

If benevolence was turning a little sour in the early nineteenth century, charitable women, more often compassionate than understanding,

1 Jordan, Philanthropy in England, $1480-1660$, p. 355, note. See also W. K. Jordan, The Charities of London, 1480-1660 (London, 1960), p. 29.

2 E. P. Thompson, The Making of the English Working Class (London, 1963), p. 57. For a balanced picture of late eighteenth- and early nineteenth-century charity, it is useful to look at Thomas Bernard's introductions to the Reports of the Society for Bettering the Condition and Increasing the Comforts of the Poor.

3 John Stuart Mill, The Subjection of Women (London, 1869), p. 163. 
must share the responsibility. As Mill remarked, the wasted resources and harmful results of charity were "immensely swelled by women's contributions, and stimulated by their influence". 1

In the years $1790-1830$ the voice of liberal or radical women was rarely heard except in the most latitudinarian charities. There were, after all, strong radical objections of principle to most forms of philanthropy. The women who worked for the expanding charities were, for the most part, conservative; but as Mill contended, their conservatism was of a sentimental variety. They seldom reflected that what they were doing was an admission of the inequalities in life and a confirmation of the existing system of class relationships. Few of them were feminists or conscious political propagandists. To serve, to be useful, that was the object. Philanthropy was both a reflection of virtue and, more pragmatically, an escape from boredom; it was outdoor relief for leisured women. As Hannah More put it, why should women be "content with polishing"? 2

Fewer and fewer of them were content with polishing as the nineteenth century progressed; more and more charities invited them to join. To leisured women this was an admission of their importance in society. Although not many of them before 1830 doubted that they enjoyed "the blessings of liberal instruction, of reasonable laws, of a pure religion, and all the endearing pleasures of an equal, social, virtuous, and delightful intercourse", ${ }^{3}$ at the back of their minds was the awareness that if they were to become more useful they would need more knowledge. Philanthropy pointed out the limitations imposed upon women at the same time as it broadened their horizons. It increased their interest in administration and the law through contact with organized charities. It increased their interest in medicine and diet through contact with disease. It increased their interest in education through contact with charity schools. Moreover, as a religion of action, philanthropy slowly challenged the complaisancy of women, gave them practical experience and responsibility, and perhaps most importantly, it heightened their self-confidence and self-respect. But in 1830 there remained much to be learned and much to be achieved.

1 Ibid.

2 More, Strictures on the Modern System of Female Education, I, p. 4.

3 Ibid., p. 3. 


\section{$A P P E N D I X$}

\section{I \\ SOCIETIES WITH TWO SUBSCRIPTION LISTS*}

Name of society and date of foundation

Benevolent, or Strangers'

Friend Society (1785)

British and Foreign

Bible Society (1804)

Church Missionary

Society (1799)

Contagious Fever

Institution (1801)

Guardian Society

(1812)

London Missionary

Society (1795)

Lying-in Charity

(1757)

Mendicity Society

(1818)

Philanthropic Society

(1788)

Prayer-Book and Homily

Society (1812)

Refuge for the Destitute

(1804)

Religious Tract Society

(1799)

Royal Lancastrian In-

stitution (1808), became

the British and Foreign

School Society (1814)

Saint Ann's Charity

School Society (1709,

reorganized in 1795)

School for the Indigent

Blind (1799)

Society for Bettering

the Condition of the

Poor (1796)

Society for Promoting

Christian Knowledge (1699)

Society for Promoting

Christianity amongst

the Jews (1808)
Dates of the two subscription lists

\begin{tabular}{|c|c|c|c|}
\hline 1802 & 598 & 81 & $14 \%$ \\
\hline 1826 & 2,574 & 812 & $32 \%$ \\
\hline 1805 & 1,482 & 173 & $12 \%$ \\
\hline 1817 & 2,712 & 612 & $23 \%$ \\
\hline 1801 & 118 & 14 & $12 \%$ \\
\hline 1823 & 1,868 & 535 & $29 \%$ \\
\hline 1803 & 448 & 35 & $8 \%$ \\
\hline 1831 & 547 & 67 & $12 \%$ \\
\hline 1815 & 465 & 126 & $27 \%$ \\
\hline $1830-31$ & 835 & 228 & $27 \%$ \\
\hline $1796 * *$ & 100 & 8 & $8 \%$ \\
\hline 1815 & 696 & 119 & $17 \%$ \\
\hline 1790 & 1,045 & 315 & $30 \%$ \\
\hline 1816 & 1,260 & 360 & $29 \%$ \\
\hline 1818 & 1,380 & 250 & $18 \%$ \\
\hline 1830 & 3,375 & 840 & $25 \%$ \\
\hline 1790 & 563 & 126 & $22 \%$ \\
\hline 1816 & 1,215 & 275 & $23 \%$ \\
\hline 1814 & 529 & 55 & $10 \%$ \\
\hline 1830 & 1,069 & 216 & $20 \%$ \\
\hline 1806 & 342 & 49 & $14 \%$ \\
\hline 1808 & 580 & 108 & $19 \%$ \\
\hline 1801 & 390 & 41 & $11 \%$ \\
\hline 1829 & 1,925 & 464 & $24 \%$ \\
\hline 1812 & 606 & 35 & $6 \%$ \\
\hline 1815 & 554 & 59 & $11 \%$ \\
\hline 1808 & 625 & 21 & $3 \%$ \\
\hline 1830 & 2,010 & 350 & $17 \%$ \\
\hline $1808 * * *$ & 1,674 & 400 & $24 \%$ \\
\hline 1816 & 444 & 126 & $28 \%$ \\
\hline 1798 & 246 & 33 & $13 \%$ \\
\hline 1805 & 598 & 183 & $31 \%$ \\
\hline $1789-90$ & 246 & 25 & $10 \%$ \\
\hline $1816-17$ & 1,828 & 368 & $20 \%$ \\
\hline 1809 & 138 & 16 & $12 \%$ \\
\hline 1813 & 1,172 & 310 & \\
\hline
\end{tabular}

Total num- Number of Women as ber of sub- women sub- a percentscribers scribers age of all subscribers

$4 \%$ $32 \%$ $12 \%$ $12 \%$ $9 \%$ $12 \%$ $7 \%$ $7 \%$ $0 \%$ $9 \%$ $18 \%$ $5 \%$ $2 \%$ $3 \%$ $10 \%$ $20 \%$ $14 \%$ $19 \%$ $1 \%$ $4 \%$ $1 \%$ $3 \%$ $17 \%$ $4 \%$ $28 \%$ $3 \%$ $31 \%$ $10 \%$ $20 \%$ $27 \%$ 


\begin{tabular}{llllr} 
Society for Promoting & $1790-92$ & 125 & 13 & $10 \%$ \\
$\begin{array}{l}\text { Religious Knowledge } \\
\text { among the Poor (1750) }\end{array}$ & $1795-97$ & 177 & 31 & $18 \%$ \\
$\begin{array}{l}\text { Society for the Support } \\
\text { and Encouragement of }\end{array}$ & 1788 & 445 & 24 & $5 \%$ \\
\hline
\end{tabular}

Sunday-Schools (1785)

* Most of these figures are for London subscribers and are given to the nearest percentage point. I apologize in advance for any careless mistakes, but I am satisfied that these would not significantly alter my percentages. I have abbreviated several of the titles; the full names of the societies can be found below.

** The London Missionary Society did not provide a list of annual subscribers until 1815. My figures for 1796 are for life subscribers. In the years $1810-15$ there were 98 life subscribers, 21 of them women.

*** The School for the Indigent Blind was not, as these figures would lead one to believe, losing its support. The figure for 1808 is for subscribers from 1799 to 1808 . The figure for 1816 is for 1816 only. In a few of the other societies as well, the lists include back subscribers. As women were increasing in number in most of the charities, the effect of this is to diminish the percentage of women for the latest date.

Sources: The Nature, Design, and Rules of the Benevolent or Strangers' Friend Society (London, 1803); The Report of the Benevolent or Strangers' Friend Society (London, 1827); The First Report of the British and Foreign Bible Society (London, 1805); The Thirteenth Report of the British and Foreign Bible Society (London, 1817); Proceedings of the Church Missionary Society for Africa and the East (London, 1801, 1823); State of the Institution for the Cure and Prevention of Contagious Fever in the Metropolis (London, 1803); The Thirtieth Report of the London Fever Hospital (London, 1832); Report of the Provisional Committee of the Guardian Society, for the Preservation of Public Morals, by Providing Temporary Asylums for Prostitutes (London, 1816); Tenth Report of the Committee of the Guardian Society (London, 1832); Four Sermons, Preached in London, at the Twenty-First General Meeting of the Missionary Society (London, 1815); Account of the Lying-in Charity for Delivering Poor Married Women at Their Own Habitations (London, 1791); Account of the Lying-in Charity (London, 1817); The First Report of the Society Established in London for the Suppression of Mendicity (London, 1819); The Thirteenth Report of the Society for the Suppression of Mendicity (London, 1831); The Philanthropic Society (London, 1790); An Account of the Nature and Present State of the Philanthropic Society (London, 1816); A Sermon Preached [...] before the Prayer-Book and Homily Society, Instituted by Members of the Established Church (London, 1814); Proceedings of the Prayer-Book and Homily Society during Its Eighteenth Year (London, 1830); A Short Account of the Institution called the Refuge for the Destitute, Cuper's-Bridge, Lambeth (London, 1806); A Short Account of the Refuge for the Destitute (London, 1808); Second Annual Report of the Religious Tract Society (London, 1801); The Thirty-First Annual Report of the Religious Tract Society (London, 1830); Report of the Finance Committee and Trustees of the Royal Lancastrian Institution for the Education of the Poor (London, 1813); Report on the Invested Subscriptions to Discharge the Debts of, and Create a Capital for the British and Foreign School Society (London, 1816); Rules and Orders of the Schools Belonging to Saint Ann's Society (London, 1808); Saint Ann's Society Schools [...] for Educating, Clothing, and Wholly Providing for Offspring of Necessitous Persons (London, 1830); An Account of the School for the Indigent Blind (London, 1808, 1816); Reports of the Society for Bettering the Condition and Increasing the Comforts of the Poor (5 vols; London, 1798-1808); An Account of the Society for Promoting Christian Knowledge (London, 1792); The Annual Report of the Society for Promoting Christian Knowledge (London, 1817); The First Report of the Committee of the London Society for Promoting Christianity amongst the Jews (London, 1809); The Fifth Report of the Committee of the London Society for Promoting Christianity amongst the Jews (London, 1813); An Account of the Society for Promoting Religious Knowledge among the Poor (London, 1797); Plan of a Society Established [...] in London for the Support and Encouragement of Sunday-Schools (London, 1789); Plan of a Society, Established in London, for the Support and Encouragement of Sunday-Schools (Bermondsey, 1812). 
SOCIETIES WITH ONE SUBSCRIPTION LIST*

\begin{tabular}{|c|c|c|c|c|}
\hline $\begin{array}{l}\text { Name of society and date } \\
\text { of foundation }\end{array}$ & $\begin{array}{l}\text { Date of } \\
\text { the sub- } \\
\text { scription } \\
\text { list }\end{array}$ & $\begin{array}{l}\text { Total num- } \\
\text { ber of sub- } \\
\text { scribers }\end{array}$ & $\begin{array}{l}\text { Number of } \\
\text { women sub- } \\
\text { scribers }\end{array}$ & $\begin{array}{l}\text { Women as a } \\
\text { percentage } \\
\text { of all sub- } \\
\text { scribers }\end{array}$ \\
\hline $\begin{array}{l}\text { The Asylum; or House of } \\
\text { Refuge (1758) }\end{array}$ & 1808 & 585 & 136 & $23 \%$ \\
\hline Christian Tract Society (1809) & 1813 & 321 & 69 & $22 \%$ \\
\hline $\begin{array}{l}\text { City of London Truss } \\
\text { Society (1807) }\end{array}$ & 1821 & 1,203 & 55 & $5 \%$ \\
\hline $\begin{array}{l}\text { Forlorn Female's Fund } \\
\text { of Mercy (1812) }\end{array}$ & 1812 & 85 & 27 & $32 \%$ \\
\hline $\begin{array}{l}\text { Institution for Rendering } \\
\text { Assistance to Shipwrecked } \\
\text { Mariners (1808) }\end{array}$ & 1809 & 54 & 1 & $2 \%$ \\
\hline $\begin{array}{l}\text { Institution for the Relief } \\
\text { of the Poor of the City of } \\
\text { London (1799) }\end{array}$ & 1800 & 1,011 & 42 & $4 \%$ \\
\hline Loan Society (1815) & 1817 & 97 & 63 & $65 \%$ \\
\hline $\begin{array}{l}\text { Lock Asylum for Penitent } \\
\text { Females (1787) }\end{array}$ & 1796 & 154 & 56 & $36 \%$ \\
\hline $\begin{array}{l}\text { National Society for Pro- } \\
\text { moting the Education of } \\
\text { the Poor (1811) }\end{array}$ & 1812 & 1,793 & 212 & $12 \%$ \\
\hline $\begin{array}{l}\text { Port of London Society } \\
\text { for Promoting Religion } \\
\text { among Seaman (1818) }\end{array}$ & 1821 & 586 & 34 & $6 \%$ \\
\hline $\begin{array}{l}\text { Refuge for the Destitute, } \\
\text { Hackney (1804) }\end{array}$ & 1818 & 1,851 & 311 & $17 \%$ \\
\hline $\begin{array}{l}\text { Royal Humane Society } \\
(1774)\end{array}$ & 1827 & 942 & 53 & $6 \%$ \\
\hline $\begin{array}{l}\text { Royal Jennerian Society } \\
\text { (1803) }\end{array}$ & 1803 & 409 & 29 & $7 \%$ \\
\hline $\begin{array}{l}\text { Society for Relitf of } \\
\text { the Destitute Sick (1785) }\end{array}$ & 1817 & 366 & 111 & $30 \%$ \\
\hline $\begin{array}{l}\text { Society for Relief of } \\
\text { Widows and Orphans of } \\
\text { Medical Men (1788) }\end{array}$ & 1818 & 183 & 14 & $8 \%$ \\
\hline $\begin{array}{l}\text { Society for Superseding } \\
\text { the Necessity of Climbing } \\
\text { Boys (1803) }\end{array}$ & 1818 & 693 & 152 & $22 \%$ \\
\hline $\begin{array}{l}\text { Society for the Diffusion } \\
\text { of Knowledge upon the } \\
\text { Punishment of Death (1808) }\end{array}$ & $1810-11$ & 288 & 24 & $8 \%$ \\
\hline $\begin{array}{l}\text { Society for the Discharge } \\
\text { and Relief of Persons } \\
\text { Imprisoned for Small } \\
\text { Debts (1772) }\end{array}$ & 1794 & 956 & 170 & $18 \%$ \\
\hline
\end{tabular}




\begin{tabular}{lcccr}
$\begin{array}{l}\text { Society for the Propagation } \\
\text { of the Gospel in }\end{array}$ & $1821 * *$ & 777 & 113 & $15 \%$ \\
$\begin{array}{l}\text { Foreign Parts (1701) } \\
\begin{array}{l}\text { Society for the Suppression } \\
\text { of Vice (1802) }\end{array}\end{array}$ & 1803 & 564 & 177 & $31 \%$ \\
$\begin{array}{l}\text { Society of Friends of } \\
\begin{array}{l}\text { Foreigners in Distress (1807) } \\
\text { Society of Unitarian }\end{array}\end{array}$ & 1814 & 906 & 32 & $4 \%$ \\
$\begin{array}{l}\text { Christians, for Promoting } \\
\text { Christian Knowledge (1807) }\end{array}$ & 1817 & 260 & 20 & $8 \%$ \\
\hline
\end{tabular}

* All of these 22 charities were managed by men. For the ladies' societies see p. 430 of the text and footnotes. I have abbreviated several of the titles; the full names of the societies can be found below. A report for the Scottish Missionary Society is available, but because the charity was not founded in England I have left it out of the Appendix. In the Report of the Scottish Missionary Society for 1824 (Edinburgh, 1824) 445 subscribers are given, 125 of them women $(28 \%)$.

** Earlier subscription lists are available for the Society for the Propagation of the Gospel in Foreign Parts, but because of their format it is impossible to determine the percentage of women in them.

Sources: An Abstract from the Account of the Asylum; or House of Refuge: Situate in the Parish of Lambeth (London, 1809); Rules of the Christian Tract Society (London, 1813); City of London Truss Society, for the Relief of the Ruptured Poor throughout the Kingdom (London, 1822); Fund of Mercy; or an Institution for the Relief and Employment of Destitute and Forlorn Females (London, 1813); Plan of an Institution, for Rendering Assistance to Shipwrecked Mariners (London, 1810); Report of the State and Progress of the Institution for the Relief of the Poor of the City of London and Parts Adjacent (London, 1800); The Second Annual Report of the Loan Society (London, 1817); An Account of the Institution of the Lock Asylum for the Reception of Penitent Females (London, 1796); First Annual Report of the National Society for Promoting the Education of the Poor in the Principles of the Established Church (London, 1812); Proceedings at the Third Anniversary of the Port of London Society for Promoting Religion among Seaman (London, 1821); A Short Account of the Refuge for the Destitute, Hackney Road, and Hoxton (London, 1818); The Fifty-Third Annual Report of the Royal Humane Society for the Recovery of Persons Apparently Drowned (London, 1827); Address of the Royal Jennerian Society for the Extermination of Small-Pox (London, 1803); Report of the Society for Relief of the Destitute Sick (London, 1817); Society for Relief of Widows and Orphans of Medical Men, in London and Its Vicinity (London, 1818); Address from the Committee of the Society for Superseding the Necessity of Climbing Boys (London, 1818); An Account of the Origin and Object of the Society for the Diffusion of Knowledge upon the Punishment of Death, and the Improvement of Prison Discipline (London, 1812); An Account of the Rise, Progress, and Present State, of the Society for the Discharge and Relief of Persons Imprisoned for Small Debts (London, 1794); A Sermon Preached before the Incorporated Society for the Propagation of the Gospel in Foreign Parts (London, 1822); Part the First, of an Address to the Public, from the Society for the Suppression of Vice (London, 1803); Account of the Society of Friends of Foreigners in Distress (London, 1814); Rules of the Society of Unitarian Christians, for Promoting Christian Knowledge and Virtue (London, 1817). 